\title{
Leprosy: An Overview of Pathophysiology
}

\author{
Ramesh Marne Bhat and Chaitra Prakash \\ Department of Dermatology, Father Muller Medical College, Karnataka, Mangalore 572002, India
}

Correspondence should be addressed to Ramesh Marne Bhat, rameshderma@gmail.com

Received 25 May 2012; Accepted 25 July 2012

Academic Editor: Eliete Caló Romero

Copyright ( 2012 R. M. Bhat and C. Prakash. This is an open access article distributed under the Creative Commons Attribution License, which permits unrestricted use, distribution, and reproduction in any medium, provided the original work is properly cited.

\begin{abstract}
Leprosy, also known as Hansen's disease, is a chronic infectious disease caused by Mycobacterium leprae, a microorganism that has a predilection for the skin and nerves. The disease is clinically characterized by one or more of the three cardinal signs: hypopigmented or erythematous skin patches with definite loss of sensation, thickened peripheral nerves, and acid-fast bacilli detected on skin smears or biopsy material. M. leprae primarily infects Schwann cells in the peripheral nerves leading to nerve damage and the development of disabilities. Despite reduced prevalence of $M$. leprae infection in the endemic countries following implementation of multidrug therapy (MDT) program by WHO to treat leprosy, new case detection rates are still high-indicating active transmission. The susceptibility to the mycobacteria and the clinical course of the disease are attributed to the host immune response, which heralds the review of immunopathology of this complex disease.
\end{abstract}

\section{Introduction}

Leprosy, also known as Hansen's disease, is a chronic infectious disease caused by Mycobacterium leprae, a microorganism that has a predilection for the skin and nerves. Though nonfatal, leprosy is one of the most common causes of nontraumatic peripheral neuropathy worldwide. The disease has been known to man since time immemorial. DNA taken from the shrouded remains of a man discovered in a tomb next to the old city of Jerusalem shows him to be the earliest human proven to have suffered from leprosy. The remains were dated by radiocarbon methods to $1-50$ A.D. [1]. The disease probably originated in Egypt and other Middle Eastern countries as early as 2400 BCE. An apparent lack of knowledge about its treatment facilitated its spread throughout the world. Mycobacterium leprae, the causative agent of leprosy, was discovered by G. H. Armauer Hansen in Norway in 1873 , making it the first bacterium to be identified as causing disease in humans $[2,3]$. Over the past 20 years, the WHO implementation of MDT has rendered leprosy a less prevalent infection in $90 \%$ of its endemic countries with less than one case per 10,000 population. Though, it continues to be a public health problem in countries like Brazil, Congo, Madagascar, Mozambique, Nepal, and Tanzania [4].

\section{Mycobacterium leprae}

M. leprae, an acid-fast bacillus is a major human pathogen. In addition to humans, leprosy has been observed in ninebanded armadillo and three species of primates [5]. The bacterium can also be grown in the laboratory by injection into the footpads of mice [6]. Mycobacteria are known for their notoriously slow growth. With the doubling time of 14 days, $M$. leprae has not yet been successfully cultured in vitro $[7,8]$. The genome of $M$. leprae has been sequenced in totality [9]. It presents with less than $50 \%$ coding capacity with a large number of pseudogenes. The remaining $M$. leprae genes help to define the minimal gene set necessary for in vivo survival of this mycobacterial pathogen as well as genes potentially required for infection and pathogenesis seen in leprosy.

M. lepromatosis is a newly identified mycobacterium which is described to cause disseminated leprosy whose significance is still not clearly understood $[10,11]$.

\section{Genetic Determinants of Host Response}

Human genetic factors influence the acquisition of leprosy and the clinical course of disease [12]. Single-nucleotide 
polymorphism (SNP) association studies showed a low lymphotoxin- $\alpha$ (LTA)-producing allele as a major genetic risk factor for early onset leprosy [13]. Other SNPs to be associated with disease and/or the development of reactions in several genes, such as vitamin D receptor (VDR), TNF- $\alpha$, IL10 , IFN- $\gamma$, HLA genes, and TLR1 are also suggested [14-17]. Linkage studies have identified polymorphic risk factors in the promoter region shared by two genes: PARK2, coding for an E3-ubiquitin ligase designated Parkin, and PACRG [18]. A study also suggests that NOD2 genetic variants are associated with susceptibility to leprosy and the development of reactions (type I and type II) [19].

\section{Transmission}

Two exit routes of $M$. leprae from the human body often described are the skin and the nasal mucosa. Lepromatous cases show large numbers of organisms deep in the dermis, but whether they reach the skin surface in sufficient numbers is doubtful [20]. Although there are reports of acid-fast bacilli being found in the desquamating epithelium of the skin, there are reports that no acid-fast bacilli were found in the epidermis, even after examining a very large number of specimens from patients and contacts [21]. However, fairly large numbers of $M$. leprae were found in the superficial keratin layer of the skin of lepromatous leprosy patients, suggesting that the organism could exit along with the sebaceous secretions [22]. The quantity of bacilli from nasal mucosal lesions in lepromatous leprosy ranges from 10,000 to $10,000,000$ [23]. Majority of lepromatous patients show leprosy bacilli in their nasal secretions as collected through blowing the nose [24]. Nasal secretions from lepromatous patients could yield as much as 10 million viable organisms per day [25].

The entry route of $M$. leprae into the human body is also not definitively known. The skin and the upper respiratory tract are most likely; however, recent research increasingly favours the respiratory route $[26,27]$.

\section{Incubation Period}

Measuring the incubation period in leprosy is difficult because of the lack of adequate immunological tools and slow onset of the disease. The minimum incubation period reported is as short as a few weeks and this is based on the very occasional occurrence of leprosy among young infants [28]. The maximum incubation period reported is as long as 30 years, or over, as observed among war veterans known to have been exposed for short periods in endemic areas but otherwise living in nonendemic areas. It is generally agreed that the average incubation period is between three and ten years [29].

\section{Risk Factors}

Those living in endemic areas with poor conditions such as inadequate bedding, contaminated water, and insufficient diet, or other diseases that compromise immune function are at highest risk for acquiring $M$. leprae infection. There has been concern that coinfection with HIV might exacerbate the pathogenesis of leprosy lesions and/or lead to increased susceptibility to leprosy as it is seen with tuberculosis. However, HIV infection has not been reported to increase susceptibility to leprosy, impact on immune response to $M$. leprae, or to have a significant effect on the pathogenesis of neural or skin lesions to date $[30,31]$. On the contrary, initiation of antiretroviral treatment has been reported to be associated with activation of subclinical M. leprae infection and exacerbation of existing leprosy lesions (type I reaction) likely as part of immune reconstitution inflammatory syndrome [32-34].

\section{Interaction of $M$. leprae with Schwann Cells and Macrophages}

Schwann cells (SCs) are a major target for infection by $M$. leprae leading to injury of the nerve, demyelination, and consequent disability. Binding of $M$. leprae to SCs induces demyelination and loss of axonal conductance [35]. It has been shown that M. leprae can invade SCs by a specific lamininbinding protein of $21 \mathrm{kDa}$ in addition to PGL-1 [36, 37]. PGL-1, a major unique glycoconjugate on the M. leprae surface, binds laminin-2, which explains the predilection of the bacterium for peripheral nerves [37]. The identification of the $M$. leprae-targeted SC receptor, dystroglycan (DG), suggests a role for this molecule in early nerve degeneration [38]. Mycobacterium leprae-induced demyelination is a result of direct bacterial ligation to neuregulin receptor, ErbB2 and Erk1/2 activation, and subsequent MAP kinase signaling and proliferation [39].

Macrophages are one of the most abundant host cells to come in contact with mycobacteria. Phagocytosis of $M$. leprae by monocyte-derived macrophages can be mediated by complement receptors CR1 (CD35), CR3 (CD11b/CD18), and CR4 (CD11c/CD18) and is regulated by protein kinase $[40,41]$. Nonresponsiveness towards M. leprae seems to correlate with a Th2 cytokine profile.

\section{Disease Classification}

Leprosy is classified within two poles of the disease with transition between the clinical forms [42]. Clinical, histopathological, and immunological criteria identify five forms of leprosy: tuberculoid polar leprosy (TT), borderline tuberculoid (BT), midborderline (BB), borderline lepromatous (BL), and lepromatous polar leprosy (LL). Patients were divided into two groups for therapeutic purposes: paucibacillary (TT, BT) and multibacillary (midborderline (BB), BL, LL) [43]. It was recommended later that the classification is to be based on the number of skin lesions, less than or equal to five for paucibacillary $(\mathrm{PB})$ and greater than five for the multibacillary (MB) form.

\section{Clinical Features (Table 1)}

9.1. Indeterminate Leprosy. Indeterminate (I) is a prelude to the determinate forms of leprosy $[44,45]$. It is characterized by an ill-defined, bizarre hypopigmented macule(s) with 
TABle 1: Clinical features of leprosy.

\begin{tabular}{|c|c|c|c|c|c|}
\hline Characteristics & Tuberculoid & Borderline tuberculoid & Midborderline & $\begin{array}{l}\text { Borderline } \\
\text { lepromatous }\end{array}$ & Lepromatous leprosy \\
\hline Number of lesions & Single or upto 3 & A Few (up to 10 ) & Several $(10-30)$ & $\begin{array}{l}\text { Numerous, } \\
\text { asymmetrical } \\
(>30)\end{array}$ & $\begin{array}{l}\text { Innumerable, } \\
\text { symmetrical }\end{array}$ \\
\hline Size & Variable, usually large & Variable, some are large & Variable & $\begin{array}{l}\text { Small, some } \\
\text { can be large }\end{array}$ & Small \\
\hline Surface changes & Hypopigmented & $\begin{array}{l}\text { Dry, scaly, look bright, } \\
\text { and infiltrated }\end{array}$ & Dull or slightly shiny & Shiny & Shiny \\
\hline Sensations & Absent & Markedly diminished & Moderately diminished & $\begin{array}{l}\text { Slightly } \\
\text { diminished }\end{array}$ & Minimally diminished \\
\hline Hair growth & Nil & Markedly diminished & Moderately diminished & $\begin{array}{l}\text { Slightly } \\
\text { diminished }\end{array}$ & Not affected initially \\
\hline Skin smear & Negative & Negative or $1+$ & $1-3+$ & $3-5+$ & $\begin{array}{l}\text { Plenty, including glob } \\
(6+)\end{array}$ \\
\hline Lepromin test & Strongly positive & Weakly positive & Negative & Negative & Negative \\
\hline
\end{tabular}

a smooth or scaly surface. The sensations over the macule may or may not be impaired. The nerve proximal to the patch may or may not be thickened.

9.2. Polyneuritic Leprosy. Manifesting with only neural signs without any evidence of skin lesions, polyneuritic leprosy mostly well recognized in the Indian subcontinent. The affected nerves are thickened, tender, or both. Localized involvement of the nerves may form nerve abscesses [46].

9.3. Histoid Leprosy. Histoid leprosy is relatively uncommon, distinct clinical, and bacteriologic and histopathologic expression of multibacillary leprosy [47]. It may occur as a primary manifestation of the disease or in consequence to secondary drug resistance to dapsone following irregular and inadequate monotherapy. It manifests as numerous cutaneous nodules and plaques primarily over the back, buttocks, face, and bony prominences.

\section{Histopathological Reactions}

Histopathologically, skin lesions from tuberculoid patients are characterized by inflammatory infiltrate containing wellformed granulomas with differentiated macrophages, epithelioid and giant cells, and a predominance of $\mathrm{CD} 4^{+} \mathrm{T}$ cells at the lesion site, with low or absent bacteria. Patients show a vigorous-specific immune response to $M$. leprae with a Th1 profile, IFN- $\gamma$ production, and a positive skin test (lepromin or Mitsuda reaction).

Lepromatous patients present with several skin lesions with a preponderance of $\mathrm{CD}^{+} \mathrm{T}$ cells in situ, absence of granuloma formation, high bacterial load, and a flattened epidermis [48]. The number of bacilli from a newly diagnosed lepromatous patient can reach $10^{12}$ bacteria per gram of tissue. Patients with LL leprosy have a CD4:CD8 ratio of approximately $1: 2$ with a predominant Th2 type response and high titers of anti- $M$. leprae antibodies. Cell-mediated immunity against $M$. leprae is either modest or absent, characterized by negative skin test and diminished lymphocyte proliferation $[49,50]$.

\section{Leprosy Reactions}

Leprosy reactions are the acute episodes of clinical inflammation occurring during the chronic course of disease. They pose a challenging problem because they increase morbidity due to nerve damage even after the completion of treatment. They are classified as type I (reversal reaction; RR) or type II (erythema nodosum leprosum; ENL) reactions. Type I reaction occurs in borderline patients (BT, midborderline and $\mathrm{BL}$ ) whereas ENL only occurs in BL and LL forms. Reactions are interpreted as a shift in patients' immunologic status. Chemotherapy, pregnancy, concurrent infections, and emotional and physical stress have been identified as predisposing conditions to reactions [51]. Both types of reactions have been found to cause neuritis, representing the primary cause of irreversible deformities.

Type I reaction is characterized by edema and erythema of existing skin lesions, the formation of new skin lesions, neuritis, additional sensory and motor loss, and edema of the hands, feet, and face, but systemic symptoms are uncommon. The presence of an inflammatory infiltrate with a predominance of $\mathrm{CD}^{+} \mathrm{T}$ cells, differentiated macrophages and thickened epidermis have been observed in RR. Type II reaction is characterized by the appearance of tender, erythematous, subcutaneous nodules located on apparently normal skin, and is frequently accompanied by systemic symptoms, such as fever, malaise, enlarged lymph nodes, anorexia, weight loss, arthralgia, and edema. Additional organs including the testes, joints, eyes, and nerves may also be affected. There may be significant leukocytosis that typically recedes after the reactional state. Presence of high levels of proinflammatory cytokines such as TNF- $\alpha$, IL-6, and IL$1 \beta$ in the sera of ENL patients suggests that these pleiotropic inflammatory cytokines may be at least partially responsible for the clinical manifestations of a type II reaction $[52,53]$.

\section{Immunology of Leprosy Reactions}

Type I reaction is a naturally occurring delayed-type hypersensitivity response to $M$. leprae. Clinically, it is characterized 
by "upgrading" of the clinical picture towards the tuberculoid pole, including a reduction in bacillary load. Immunologically, it is characterized by the development of strong skin test reactivity as well as lymphocyte responsiveness and a predominant Th1 response $[54,55]$. RR episodes have been associated with the infiltration of IFN- $\gamma$ and TNF-secreting $\mathrm{CD}^{+}$lymphocytes in skin lesions and nerves, resulting in edema and painful inflammation [56, 57]. Immunologic markers like CXCL10 are described as a potential tool for discriminating RR [58]. A significant increase in FoxP3 staining was observed in RR patients compared with ENL and patients with nonreactional leprosy, implying a role for regulatory T cells in RR [59].

Pathogenesis of type II reaction is thought to be related to the deposition of immune complexes [60]. Increased levels of TNF- $\alpha$, IL- $1 \beta$, IFN- $\gamma$, and other cytokines in type II reactions are observed [61-63]. In addition, C-reactive protein, amyloid A protein, and $\alpha-1$ antitrypsin have also been reported to be elevated in ENL patients' sera [64]. A massive infiltrate of polymorphonuclear cells (PMN) in the lesions is only observed during ENL and some patients present with high numbers of neutrophils in the blood as well. Neutrophils may contribute to the bulk of TNF production that is associated with tissue damage in leprosy. More recently, microarray analysis demonstrated that the mechanism of neutrophil recruitment in ENL involves the enhanced expression of E-selectin and IL- $1 \beta$, likely leading to neutrophil adhesion to endothelial cells; again, an effect of thalidomide on PMN function was observed since this drug inhibited the neutrophil recruitment pathway [65]. Altogether, the data highlight some of the possible mechanisms for thalidomide's efficacy in treating type II reaction. TNF- $\alpha$ may augment the immune response towards the elimination of the pathogen and/or mediate the pathologic manifestations of the disease. TNF- $\alpha$ can be induced following stimulation of cells with total, or components of $M$. leprae, namely, lipoarabinomannan (the mycobacteria "lipopolysaccharide-" like component) a potent TNF inducer [66]. In addition, mycolyl-arabinogalactan-peptidoglycan complex of Mycobacterium species, the protein-peptidoglycan complex, and muramyl dipeptide all elicit significant TNF- $\alpha$ release [66].

\section{References}

[1] DNA of Jesus-Era Shrouded Man in Jerusalem Reveals Earliest Case of Leprosy, 2009.

[2] G. H. A. Hansen, "Investigations concerning the etiology of leprosy," Norsk Magazin for Logevidenskaben, vol. 4, pp. 1-88, 1874 (Norwegian).

[3] L. M. Irgens, "The discovery of the leprosy bacillus," Tidsskrift for den Norske Laegeforening, vol. 122, no. 7, pp. 708-709, 2002.

[4] P. E. M. Fine, "Global leprosy statistics: a cause for pride, or frustration?” Leprosy Review, vol. 77, no. 4, pp. 295-297, 2006.

[5] O. Rojas-Espinosa and M. Løvik, "Mycobacterium leprae and Mycobacterium lepraemurium infections in domestic and wild animals," OIE Revue Scientifique et Technique, vol. 20, no. 1, pp. 219-251, 2001.

[6] R. C. Hastings, T. P. Gillis, J. L. Krahenbuhl, and S. G. Franzblau, "Leprosy," Clinical Microbiology Reviews, vol. 1, no. 3, pp. 330-348, 1988.
[7] N. Rastogi, E. Legrand, and C. Sola, "The Mycobacteria: an introduction to nomenclature and pathogenesis," OIE Revue Scientifique et Technique, vol. 20, no. 1, pp. 21-54, 2001.

[8] M. C. Gutierrez, P. Supply, and R. Brosch, "Pathogenomics of mycobacteria," Genome Dynamics, vol. 6, pp. 198-210, 2009.

[9] S. T. Cole, K. Eiglmeier, J. Parkhill et al., "Massive gene decay in the leprosy bacillus," Nature, vol. 409, no. 6823, pp. 10071011, 2001.

[10] X. Y. Han, Y. H. Seo, K. C. Sizer et al., "A new Mycobacterium species causing diffuse lepromatous leprosy," American Journal of Clinical Pathology, vol. 130, no. 6, pp. 856-864, 2008.

[11] X. Y. Han, K. C. Sizer, E. J. Thompson et al., "Comparative sequence analysis of Mycobacterium leprae and the new leprosy-causing Mycobacterium lepromatosis," Journal of Bacteriology, vol. 191, no. 19, pp. 6067-6074, 2009.

[12] A. Alter, A. Alcaïs, L. Abel, and E. Schurr, "Leprosy as a genetic model for susceptibility to common infectious diseases," Human Genetics, vol. 123, no. 3, pp. 227-235, 2008.

[13] A. Alcaïs, A. Alter, G. Antoni et al., "Stepwise replication identifies a low-producing lymphotoxin- $\alpha$ allele as a major risk factor for early-onset leprosy," Nature Genetics, vol. 39, no. 4, pp. 517-522, 2007.

[14] A. R. Santos, P. N. Suffys, P. R. Vanderborght et al., "TNF $\alpha$ and IL-10 promoter polymorphisms in leprosy: association with disease susceptibility," Journal of Infectious Diseases, vol. 186, no. 11, pp. 1687-1691, 2002.

[15] M. T. Mira, A. Alcais, T. di Pietrantonio et al., "Segregation of HLA/TNF region is linked to leprosy clinical spectrum in families displaying mixed leprosy subtypes," Genes and Immunity, vol. 4, no. 1, pp. 67-73, 2003.

[16] E. A. Misch, M. Macdonald, C. Ranjit et al., "Human TLR1 deficiency is associated with impaired mycobacterial signaling and protection from leprosy reversal reaction," PLoS Neglected Tropical Diseases, vol. 2, no. 5, article e231, 2008.

[17] C. C. Cardoso, A. C. Pereira, V. N. Brito-De-Souza et al., "IFNG $+874 \mathrm{~T}>\mathrm{A}$ single nucleotide polymorphism is associated with leprosy among Brazilians," Human Genetics, vol. 128, no. 5, pp. 481-490, 2010.

[18] M. T. Mira, A. Alcaïs, H. Van Thuc et al., "Susceptibility to leprosy is associated with PARK2 and PACRG," Nature, vol. 427, no. 6975, pp. 636-640, 2004.

[19] W. R. Berrington, M. Macdonald, S. Khadge et al., "Common polymoiphisms in the NOD2 gene region are associated with leprosy and Its reactive states," Journal of Infectious Diseases, vol. 201, no. 9, pp. 1422-1435, 2010.

[20] What Is Leprosy?, THE MEDICAL NEWS-from News-Medical.Net. Latest Medical News and Research from Around the World, 2010.

[21] G. Weddell and E. Palmer, "The pathogenesis of leprosy. An experimental approach,” Leprosy Review, vol. 34, pp. 57-61, 1963.

[22] C. K. Job, J. Jayakumar, and M. Aschhoff, "Large numbers of Mycobacterium leprae are discharged from the intact skin of lepromatous patients; A preliminary report," International Journal of Leprosy and Other Mycobacterial Diseases, vol. 67, no. 2, pp. 164-167, 1999.

[23] C. C. Shepard, "Acid-fast bacilli in nasal excretions in leprosy, and results of inoculation of mice," American Journal of Epidemiology, vol. 71, no. 2, pp. 147-157, 1960.

[24] J. C. Pedley, “The nasal mucus in leprosy," Leprosy Review, vol. 44, no. 1, pp. 33-35, 1973.

[25] T. F. Davey and R. J. W. Rees, "The nasal discharge in leprosy: clinical and bacteriological aspects," Leprosy Review, vol. 45, no. 2, pp. 121-134, 1974. 
[26] R. J. W. Rees and A. C. McDougall, "Airborne infection with Mycobacterium leprae in mice," Journal of Medical Microbiology, vol. 10, no. 1, pp. 63-68, 1977.

[27] S. Chehl, C. K. Job, and R. C. Hastings, "Transmission of leprosy in nude mice," American Journal of Tropical Medicine and Hygiene, vol. 34, no. 6, pp. 1161-1166, 1985.

[28] E. Montestruc and R. Berdonneau, "2 New cases of leprosy in infants in Martinique," Bulletin de la Société de Pathologie Exotique et de ses Filiales, vol. 47, no. 6, pp. 781-783, 1954.

[29] R. O. Pinheiro, J. De Souza Salles, E. N. Sarno, and E. P. Sampaio, "Mycobacterium leprae-host-cell interactions and genetic determinants in leprosy: an overview," Future Microbiology, vol. 6, no. 2, pp. 217-230, 2011.

[30] E. P. Sampaio, J. R. T. Caneshi, J. A. C. Nery et al., "Cellular immune response to Mycobacterium leprae infection in human immunodeficiency virus-infected individuals," Infection and Immunity, vol. 63, no. 5, pp. 1848-1854, 1995.

[31] J. A. C. Nery, E. P. Sampaio, M. C. G. Galhardo et al., "M. leprae-HIV co-infection: pattern of immune response in vivo and in vitro," Indian Journal of Leprosy, vol. 72, no. 2, pp. 155167,2000

[32] E. N. Sarno, X. Illarramendi, J. A. Costa Nery et al., "HIV-M. leprae interaction: can HAART modify the course of leprosy?" Public Health Reports, vol. 123, no. 2, pp. 206-212, 2008.

[33] P. D. Deps and D. N. J. Lockwood, "Leprosy occurring as immune reconstitution syndrome," Transactions of the Royal Society of Tropical Medicine and Hygiene, vol. 102, no. 10, pp. 966-968, 2008.

[34] P. Couppié, V. Domergue, E. Clyti et al., "Increased incidence of leprosy following HAART initiation: a manifestation of the immune reconstitution disease," AIDS, vol. 23, no. 12, pp. 1599-1600, 2009.

[35] A. Rambukkana, G. Zanazzi, N. Tapinos, and J. L. Salzer, "Contact-dependent demyelination by Mycobacterium leprae in the absence of immune cells," Science, vol. 296, no. 5569, pp. 927-931, 2002.

[36] M. A. M. Marques, V. L. Antônio, E. N. Sarno, P. J. Brennan, and M. C. V. Pessolani, "Binding of $\alpha 2$-laminins by pathogenic and non-pathogenic mycobacteria and adherence to Schwann cells," Journal of Medical Microbiology, vol. 50, no. 1, pp. 23-28, 2001.

[37] V. Ng, G. Zanazzi, R. Timpl et al., "Role of the cell wall phenolic glycolipid-1 in the peripheral nerve predilection of $\mathrm{Myco}$ bacterium leprae," Cell, vol. 103, no. 3, pp. 511-524, 2000.

[38] A. Rambukkana, H. Yamada, G. Zanazzi et al., "Role of $\alpha$ dystroglycan as a Schwann cell receptor for Mycobacterium leprae," Science, vol. 282, no. 5396, pp. 2076-2079, 1998.

[39] N. Tapinos, M. Ohnishi, and A. Rambukkana, "ErbB2 receptor tyrosine kinase signaling mediates early demyelination induced by leprosy bacilli," Nature Medicine, vol. 12, no. 8, pp. 961-966, 2006.

[40] L. S. Schlesinger and M. A. Horwitz, "Phagocytosis of Mycobacterium leprae by human monocyte-derived macrophages is mediated by complement receptors CR1 (CD35), CR3 (CD11b/CD18), and CR4 (CD11c/CD18) and IFN- $\gamma$ activation inhibits complement receptor function and phagocytosis of this bacterium," Journal of Immunology, vol. 147, no. 6, pp. 1983-1994, 1991.

[41] K. Prabhakaran, E. B. Harris, and B. Randhawa, "Regulation by protein kinase of phagocytosis of Mycobacterium leprae by macrophages," Journal of Medical Microbiology, vol. 49, no. 4, pp. 339-342, 2000.

[42] D. S. Ridley and W. H. Jopling, "Classification of leprosy according to immunity. A five-group system," International
Journal of Leprosy and Other Mycobacterial Diseases, vol. 34, no. 3, pp. 255-273, 1966.

[43] WHO, "Chemotherapy of leprosy for control programmes," World Health Organisation Technical Report Series, vol. 675, pp. 1-33, 1982.

[44] T. T. Fajardo, "Indeterminate leprosy: a 3 year study, clinical observations," International Journal of Leprosy, vol. 39, pp. 9495, 1971.

[45] T. T. Fajardo, "Indeterminate leprosy: a five year study, clinical observations," International Journal of Leprosy, vol. 41, p. 576, 1973.

[46] V. N. Sehgal, S. M. Tuli, and B. Dube, "Leprotic nerve abscesses in northern India," International Journal of Leprosy and Other Mycobacterial Diseases, vol. 35, no. 1, pp. 60-64, 1967.

[47] V. N. Sehgal and G. Srivastava, "Status of histoid leprosy-a clinical, bacteriological, histopathological and immunological appraisal," Journal of Dermatology, vol. 14, no. 1, pp. 38-42, 1987.

[48] W. C. Van Voorhis, G. Kaplan, and E. N. Sarno, "The cutaneous infiltrates of leprosy. Cellular characteristics and the predominant T-cell phenotypes," New England Journal of Medicine, vol. 307, no. 26, pp. 1593-1597, 1982.

[49] R. L. Modlin, F. M. Hofman, C. R. Taylor, and T. H. Rea, "T lymphocyte subsets in the skin lesions of patients with leprosy," Journal of the American Academy of Dermatology, vol. 8, no. 2, pp. 182-189, 1983.

[50] D. Wallach, B. Flageul, M. A. Bach, and F. Cottenot, "The cellular content of dermal leprous granulomas: an immunohistological approach," International Journal of Leprosy, vol. 52, no. 3, pp. 318-326, 1984.

[51] C. Lienhardt and P. E. M. Fine, "Type 1 reaction, neuritis and disability in leprosy: what is the current epidemiological situation?" Leprosy Review, vol. 65, no. 1, pp. 9-33, 1994.

[52] E. N. Sarno, G. E. Grau, L. M. M. Vieira, and J. A. Nery, "Serum levels of tumour necrosis factor-alpha and interleukin- $1 \beta$ during leprosy reactional states," Clinical and Experimental Immunology, vol. 84, no. 1, pp. 103-108, 1991.

[53] S. Khanolkar-Young, N. Rayment, P. M. Brickell et al., "Tumor necrosis factor-alpha (TNF- $\alpha$ ) synthesis is associated with the skin and peripheral nerve pathology of leprosy reversal reactions," Clinical and Experimental Immunology, vol. 99, no. 2, pp. 196-202, 1995.

[54] G. Bjune, R. S. Barnetson, D. S. Ridley, and G. Kronvall, "Lymphocyte transformation test in leprosy; correlation of the response with inflammation of lesions," Clinical and Experimental Immunology, vol. 25, no. 1, pp. 85-94, 1976.

[55] T. H. Rea and N. E. Levan, "Current concepts in the immunology of leprosy," Archives of Dermatology, vol. 113, no. 3, pp. 345-352, 1977.

[56] S. Khanolkar-Young, N. Rayment, P. M. Brickell et al., "Tumor necrosis factor-alpha (TNF- $\alpha$ ) synthesis is associated with the skin and peripheral nerve pathology of leprosy reversal reactions," Clinical and Experimental Immunology, vol. 99, no. 2, pp. 196-202, 1995.

[57] D. Little, S. Khanolkar-Young, A. Coulthart, S. Suneetha, and D. N. J. Lockwood, "Immunohistochemical analysis of cellular infiltrate and gamma interferon, interleukin-12, and inducible nitric oxide synthase expression in leprosy type 1 (reversal) reactions before and during prednisolone treatment," Infection and Immunity, vol. 69, no. 5, pp. 3413-3417, 2001.

[58] M. M. Stefani, J. G. Guerra, A. L. M. Sousa et al., "Potential plasma markers of type 1 and type 2 leprosy reactions: a preliminary report," BMC Infectious Diseases, vol. 9, article 75, 2009. 
[59] C. Massone, E. Nunzi, R. Ribeiro-Rodrigues et al., "T regulatory cells and plasmocytoid dentritic cells in hansen disease: a new insight into pathogenesis?" American Journal of Dermatopathology, vol. 32, no. 3, pp. 251-256, 2010.

[60] B. Bjorvatn, R. S. Barnetson, and G. Kronvall, "Immune complexes and complement hypercatabolism in patients with leprosy," Clinical and Experimental Immunology, vol. 26, no. 3, pp. 388-396, 1976.

[61] P. Sreenivasan, R. S. Misra, D. Wilfred, and I. Nath, "Lepromatous leprosy patients show Thelper 1-like cytokine profile with differential expression of interleukin-10 during type 1 and 2 reactions," Immunology, vol. 95, no. 4, pp. 529-536, 1998.

[62] I. Nath, N. Vemuri, A. L. Reddi et al., "The effect of antigen presenting cells on the cytokine profiles of stable and reactional lepromatous leprosy patients," Immunology Letters, vol. 75 , no. 1, pp. 69-76, 2000.

[63] M. O. Moraes, E. P. Sampaio, J. A. C. Nery, B. C. C. Saraiva, F. B. F. Alvarenga, and E. N. Sarno, "Sequential erythema nodosum leprosum and reversal reaction with similar lesional cytokine mRNA patterns in a borderline leprosy patient," British Journal of Dermatology, vol. 144, no. 1, pp. 175-181, 2001.

[64] I. P. Kahawita and D. N. J. Lockwood, "Towards understanding the pathology of erythema nodosum leprosum," Transactions of the Royal Society of Tropical Medicine and Hygiene, vol. 102, no. 4, pp. 329-337, 2008.

[65] D. J. Lee, H. Li, and M. T. Ochoa, "Integrated pathways for neutrophil recruitment and inflammation in leprosy," Journal of Infectious Diseases, vol. 201, pp. 558-569, 2010.

[66] P. F. Barnes, D. Chatterjee, P. J. Brennan, T. H. Rea, and R. L. Modlin, "Tumor necrosis factor production in patients with leprosy," Infection and Immunity, vol. 60, no. 4, pp. 1441-1446, 1992. 


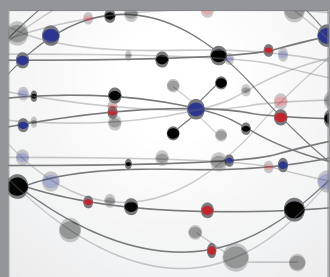

The Scientific World Journal
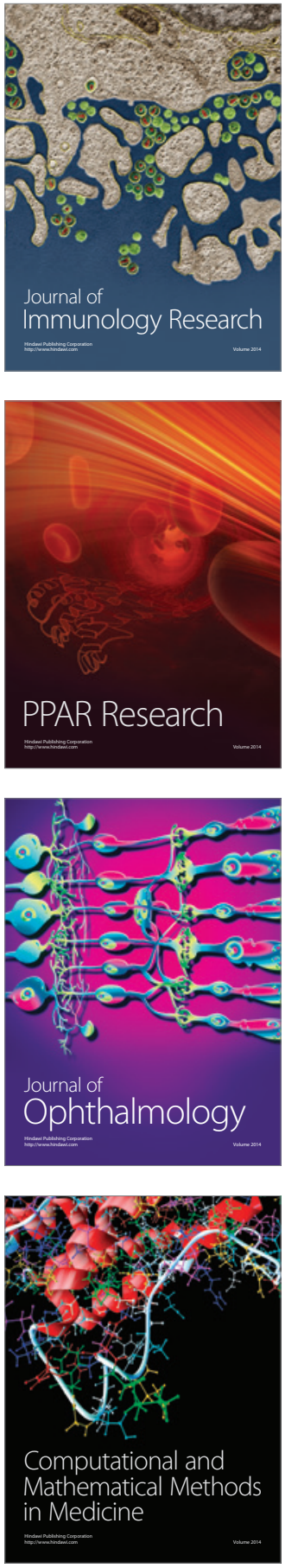

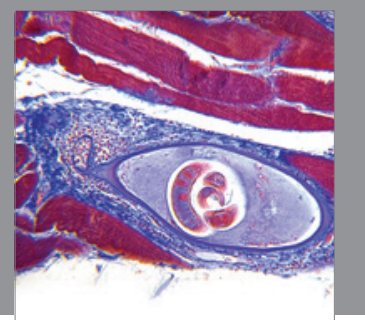

Gastroenterology

Research and Practice
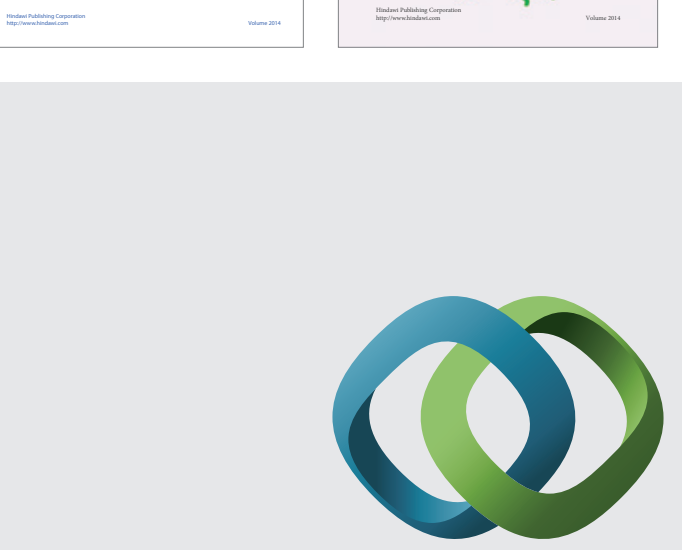

\section{Hindawi}

Submit your manuscripts at

http://www.hindawi.com
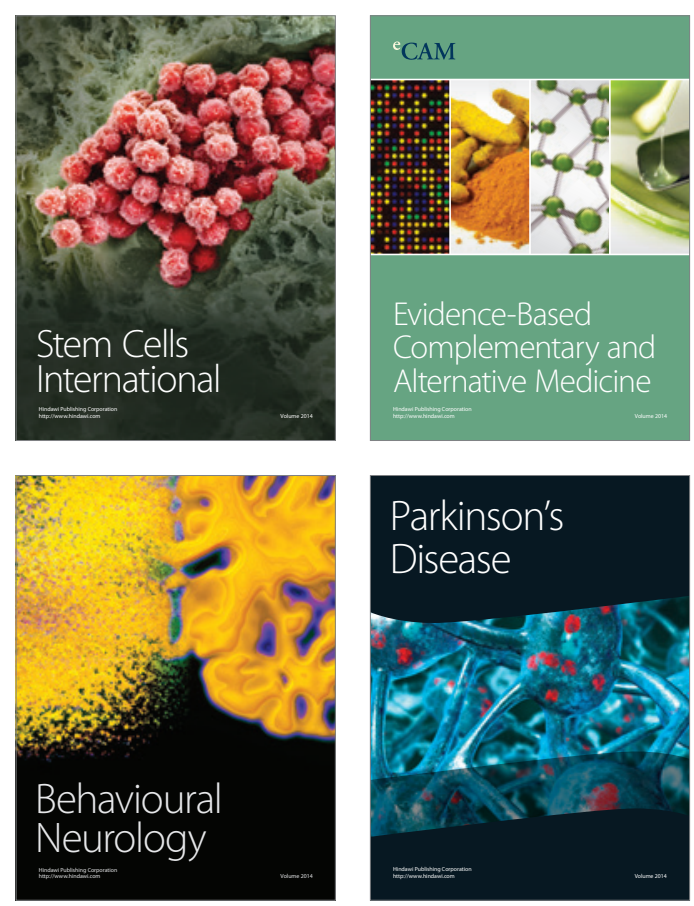

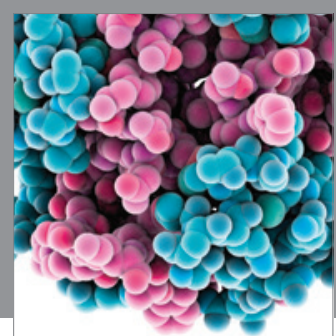

Journal of
Diabetes Research

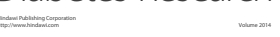

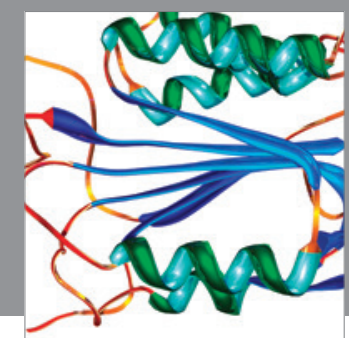

Disease Markers
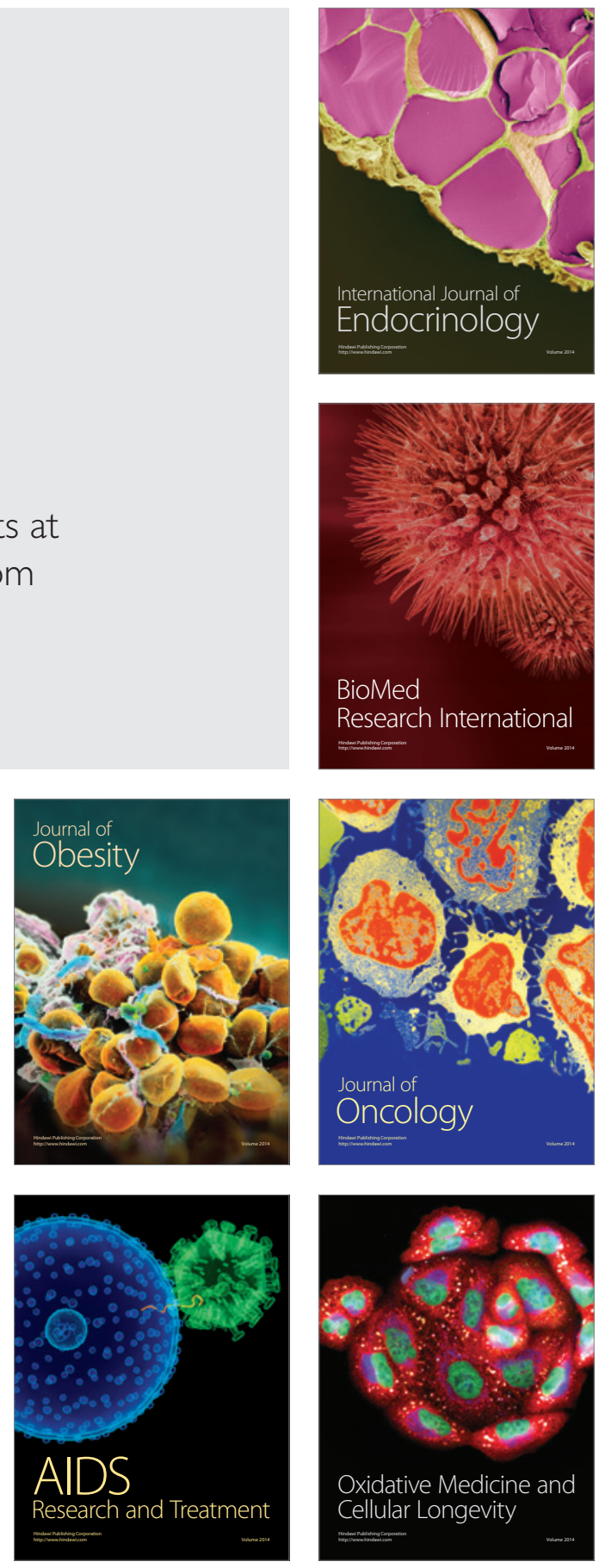